Profesora Titular de literatura hispanoamericana de la Universidad de Alicante, Directora del Secretariado de Relaciones con América Latina y del Centro Iberoamericano Mario Benedetti de la citada universidad.Ha sido antóloga y editora de obras de Miguel Hernández, entre ellas, de la Obra Completa publicada en Espasa-Calpe. En literatura hispanoamericana destacan sus estudios sobre indigenismo y sobre poesía coloquial (Poética coloquial hispanoamericana), así como numerosos trabajos sobre poesía cubana. Otra línea de su investigación es las relaciones culturales entre Espña y América Latina que se han materializado en su libro $\mathrm{El}$ meridiano intelectual en Hispanoamérica.

\section{POESía CUbana A FINALES DEL XX: 1980-2000}

\author{
CARMEN ALEMANY BAY
}

1 En «La última poesía cubana», en AA.W., La poesía nueva en el mundo hispánico, Madrid, Visor, 1994, p. 152.
Poesía cubana a finales del XX 1980-2000

CARMEN ALEMANY BAY
Cualquier lector que conozca la trayectoria de la poesía cubana desde la llegada de la Revolución es consciente de que a partir del 60 , en general, ésta sigue unas pautas muy ligadas al proceso revolucionario, y que durante casi dos décadas tuvieron vigencia temas vinculados al compromiso y a la poesía de urgencia. Cierto y lógico es que la poesía va cambiando y adaptándose a los nuevos tiempos, y ese carácter de premura del que hablábamos se va modificando en los escritores emblemáticos de la llamada «Primera Generación de la Revolución» y en las sucesivas promociones. Los compases poéticos vendrán lógicamente marcados por otras generaciones que de manera rápida e incesante se suman a la poesía cubana.

A comienzos de los 70 ocurren una serie de acontecimientos políticos que incidirán de manera directa en la literatura $y$, claramente, en la poesía. Los primeros años de esta década se abren con el Primer Congreso de Educación y Cultura (1971), desde el que se incita a los poetas a crear una obra más comprometida con la Revolución; esta consigna afectará a algunas de las voces de la «Primera Generación», a muchos de los componentes del grupo que se formó alrededor de la editorial «El Puente», así como al grupo del Caimán Barbudo. El resultado fue, como apunta Teodosio Fernández, que «la exaltación épica de la Revolución y de sus protagonistas determinó la extinción de las actitudes críticas y desacralizadoras que estaban en los orígenes de la poesía conversacional. Estas circunstancias dejaban escasas salidas para las inquietudes renovadoras» 1 .

Desde los organismos culturales se apoyó un tipo de poesía, el llamado «tojosismo» (del término «tojosa», paloma silvestre), que duró prácticamente toda la década y que dejará poca huella en los libros posteriores. De un elevado número de poetas que cultivaron esta modalidad, basada en la exaltación de la naturaleza a través de formas estróficas tradicionales como décimas, sonetos o romances, hoy en día sólo quedan algunos nombres como el de Osvaldo Navarro.

Asimismo, la situación cultural se verá agravada por el procesamiento del escritor Heberto Padilla, lo que implicará que intelectuales cubanos, pero también latinoamericanos y europeos, decidan estar al lado o no de la Revolución.

Un enrarecido ambiente cultural se une a una ingrata situación económica, conformando el llamado Quinquenio Gris (1971-1976), que para muchos se extenderá hasta finales de los 70 .

A pesar de la situación, en poesía seguirán apareciendo nuevos nombres como los propuestos en la antología Punto de partida (1970); los poemas y los poetas que en ella aparecen reseñados fueron escogidos por Raúl Rivero, el benjamín de los «caimanes», y Germán Piniella. Cuatro años más tarde sale a la luz otra antología, Nuevos poetas, de Roberto Díaz Muñoz. Los autores incluidos en ambos volúmenes siguen apostando por la continuidad temática, pero sí empieza a entreverse una voluntad de ir depurando la expresión conversacional, tan presente en la década de los 60; en cualquier caso no puede hablarse aún de una rotunda negativa de los movimientos poéticos aparecidos a partir del 59.

Muchos empezarán a ser los escritores que en la segunda mitad de la década de los 70 op- 
tarán por una poética cercana al hermetismo, con creaciones próximas a las del recién fallecido José Lezama Lima (1976). Al mismo tiempo, otro origenista, Eliseo Diego, estará en el punto de mira de los nuevos autores porque desde sus primeras obras compaginó una poética muy relacionada con el grupo Orígenes con otra que no renunciaba a la expresión abierta y muy cercana al coloquialismo.

Precisamente, la poética coloquial muy cultivada en Cuba a partir de la Revolución puso al alcance de casi todos la comprensión poética, pero pronto acabó parodiándose a sí misma y limitando otros caminos poéticos. Fue el binomio coloquialismo-Revolución el que en ocasiones acabó convirtiendo la poesía en mero instrumento de propaganda oficial. Afortunadamente, algunos poetas, los más grandes, pudieron sobreponerse a los estertores revolucionarios y seguir escribiendo poesía desde la coherencia y, sobre todo, desde la poesía, y no desde la política. Pero tendremos que esperar a los años 80 para que se pueda apreciar un verdadero cambio en la poesía cubana, cambio que se resumiría en los siguientes puntos: la individualización del sujeto del poema - ahora es el nosotros el que se diluye entre los nuevos versos para dar protagonismo al yo-; voluntad de volver a los metros y estrofas tradicionales en contra del casi siempre presente verso libre y, sobre todo, la inclusión de nuevos temas más acordes con una realidad crítica. Diferentes tonos, temas y críticas nacerán de un inevitable desasosiego cultural.

Lógicamente, la situación política y económica de los 80 en Cuba ya no es la misma y los jóvenes que encabezan ahora la renovación lírica no han vivido conscientemente los primeros años de la Revolución, sino que han nacido con ella. A esto habría que sumar un cambio de actitud por parte del gobierno cubano, que se concreta en la labor desarrollada por Hart Dávalos, al frente del Ministerio de Cultura, desde la creación de éste en 1976, y cuya tarea fue principalmente reactivar la dinámica cultural de la isla. Desde este Ministerio se hizo un llamamiento al rigor y un rechazo a la autocomplacencia: los dirigentes culturales criticarán la imposición de normas artísticas por parte de algunos funcionarios y los propios escritores denunciarán el acomodamiento y el exagerado mimetismo presente en los esquemas poéticos.
Asimismo, en los 80 se pondrá en marcha el llamado «periodo de rectificación» que, en lo que compete al mundo de la cultura, se resume en el citado espíritu crítico y una mayor apertura a la renovación. Todo esto cristalizará en numerosos actos entre los que destacaríamos el Forum de la Crítica e Investigación Literarias (1987), organizado por la UNEAC, y al que acudieron especialistas cubanos y extranjeros. Una ebulliciosa y abierta actividad cultural entrará en contraposición con la rigidez del periodo anterior.

\section{EL ANHELADO CAMBIO POÉ- TICO DE LOS 80}

Para este anhelado cambio poético no hubiese sido necesario que Cuba participase de manera activa en la guerra de Angola, que los cubanos vieran la realidad del puente migratorio de Mariel, que Ronald Reagan endureciese la relación con Cuba, que marines norteamericanos se enfrentasen con trabajadores cubanos, que se hiciese patente la deserción, la corrupción y el narcotráfico entre las personalidades del gobierno; pero el resultado de toda esta amalgama de sucesivos acontecimientos en la isla se encauzaron hacia una tímida apertura y una mayor flexibilidad de la que se aprovecharon los jóvenes poetas.

La transición se hizo evidente ya en los años 70 con la publicación de Las puertas y los pasos (1976) de Luis Lorente y La gente de mi barrio de Reina María Rodríguez ${ }^{2}$. La aparición de estos libros coincide con la muerte del poeta origenista José Lezama Lima; y así como los jóvenes del 27 español rememoraron la figura de Luis de Góngora, los jóvenes poetas cubanos homenajearán la figura de Lezama y empezarán a reivindicar una poesía más esteticista y más hermética, huyendo de la ya desgastada poética coloquial que en esos momentos se escribía en $\mathrm{Cuba}^{3}$.

Desde mi punto de vista, Reina María Rodríguez será una de las voces que más nítidamente contrastarán con la poesía anterior y la que mostrará más capacidad de generar una nueva sensibilidad en la poesía. Su obra, atenta al mundo que la rodea, intenta descubrir el asombro de lo cotidiano en un discurso directo y transparente:
2

Para Teodosio Fernández, «el primero (Las puertas y los pasos) relacionable con el tojosismo, enriquecía de símbolos la tendencia aún decididamente referencial de esa poesía. El segundo, más próximo al coloquialismo, ganaba para la poesía cubana un lirismo inusual que recuperaba la manifestación personal de inquietudes y sentimientos» («Un siglo de poesía cubana", en Susana y los viejos, 1-2, 1997, p. 176).

3

Alicia Llarena (en «De cuando echaron a rodar sus ojos verdes: para una lectura de la joven poesía cubana», en Poesía cubana de los años 80. Antología, (introducción de Alicia Llarena y Osmar Sánchez), Madrid, Ediciones La Palma, 1994) apunta sobre el lezamismo en los poetas del 80 que «hay en estos autores un especial 'empeño en la búsqueda de la riqueza cultural', y un consecuente 'mayor número de metáforas', de acuerdo con una aceptación lezamiana del hecho literario. Sin que esto último pueda aplicarse indiscriminadamente a todos los poetas, $y$ sin que esa suerte de imitación del 'lezamismo' o 'neo-origenismo' quiera decir imitación a ultranza» (p. 25)

Poesía cubana a finales del XX: 1980-2000

CARMEN ALEMANY BAY 

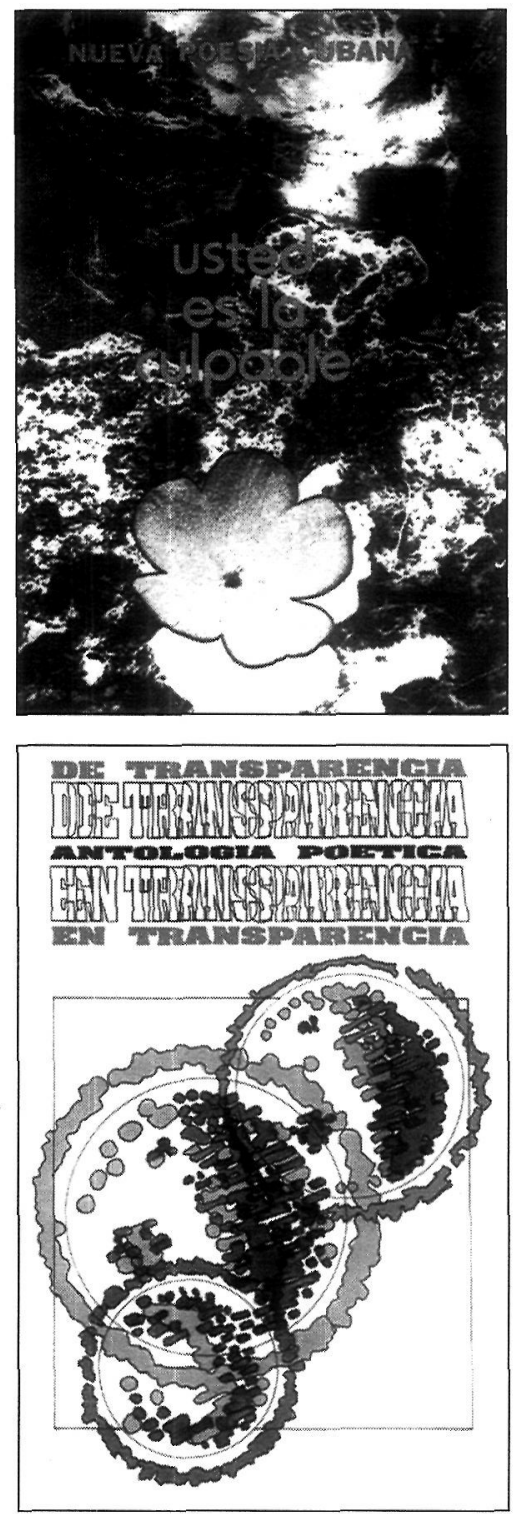

\section{4}

Estos versos aparecen antologados en Norberto Codina, Los ríos de la mañana. Poesía cubana de los 80, La Habana, Unión, 1995, p. 74. En adelante, cuando se citen versos incluidos en esta antología, sólo pondré las letras RMy el número de página. Debido a las numerosas antologías que se citan en este trabajo, utilizaré el mismo sistema. Cuando se cite de los poemas de la antología de Teodosio Fernández incluida en Susana y los viejos, op. cit., lo haremos con la letra $S$; la de Alicia Llarena, op. cit., con las letras PC; Usted es la culpable (La Habana, Abril, 1985) con Ud.; Retrato de grupo (La Habana, Letras Cuba-

Poesía cubana a finales del XX: 1980-2000

CARMEN ALEMANY BAY

llegar a mí. una casa vacía

y ni un solo tesoro.

todo desierto en las esquinas.

cargo con mi casa inmueble desperdicio

el silencio en los túneles

ni siquiera secretos

«Alguna vez. Algún tiempo»4

Por su parte, Luis Lorente enriquecerá el discurso poético mostrando una realidad recogida a retazos: «La vena de su frente y la corbata, renuncian/ a su aspecto de redactar humilde» $(\mathrm{RM}, 60)$, para llevarla hacia otras realidades insospechadas para el lector.

A esos nombres habría que añadir otros cuya obra empezará a tenerse en cuenta a comienzos de los años 80 , la mayoría de los cuales incluidos en Usted es la culpable (1985): Albis Torres, Raúl Hernández Novás, Aramis Quintero, José Pérez Olivares, Soleida Ríos, Abel Díaz Castro, Norberto Codina, Bladimir Zamora, Efraín Rodríguez, Cira Andrés, Alex Fleites, Marilyn Bobes, Víctor Rodríguez Núñez, Ángel Escobar, Roberto Méndez, Osvaldo Sánchez, Ramón Fernández-Larrea y Sigfredo Ariel ${ }^{5}$. Fuera de la antología pero también representativos de este momento de cambio son los nombres de Emilio de Armas, Alberto Serret, Reinaldo Montero, Abilio Estévez, León de la Hoz o Roberto Méndez, quienes, igualmente, contribuyeron a crear «una poesía mucho me-

nas, 1989) con R y De transparencia en transparencia (La Habana, Letras Cubanas, 1993) con Tr.

5

Antes de la publicación de esta antología aparecerá otra, publicada en México, Cuba: en su lugar la poesía, de 1982, y antologada por Víctor Rodríguez Núñez, en la que ya aparecen muestras de la nueva poesía.

6

Así la ha definido Reina María Rodríguez en una entrevista realizada por Emilio Bejel, Escribir en Cuba. Entrevistas con escritores cubanos: 1979-
1989, Río Piedras, Universidad de Puerto Rico, 1991, p. 349.

\section{7}

El poema de Roberto Fernández Retamar dice así: «Nosotros, los sobrevivientes, / ¿A quiénes debemos la sobrevida?/ ¿Quién se murió por mí en la ergástula, / Quién recibió la bala mía, / La para mí, en su corazón?/ ¿Sobre qué muerto estoy yo vivo,/ Sus huesos quedando en los míos, / Los ojos que le arrancaron, viendo/ Por la mirada de mi cara/ $Y$ la mano que no es su mano,/ Que no es ya tampoco la mía, / Escribiendo palabras rotas/ Donde él no está, en la sobrevida?». nos épica y más ética»; una ética que lleva implícita posiciones más reflexivas, menos flemáticas, y más acordes con los nuevos tiempos, como se puede leer en «Identidad» de Marilyn Bobes:

No salgo con pancartas a la calle porque mi tiempo es otro.

Honro a mis muertos con cada sonrisa.

No salgo con pancartas a la calle porque mi tiempo es otro.

Pero tengo 22 años, las manos limpias

y si en algún lugar me necesitan

no tendrán siquiera que llamarme (Ud, 130)

La rebeldía personal irá acompañada de otra de índole poética, como apreciamos en el siguiente poema de Ramón Fernández-Larrea, en el que se parafrasean los primeros versos de «El otro» de Fernández Retamar:

\section{GENERACIÓN}

Nosotros los sobrevivientes

a nadie debemos la sobrevida

todo rencor estuvo en su lugar

estar en Cuba a las dos de la tarde

es un acto de fe

no conocía mi rostro el frank con su pistola

yo tampoco conozco la cara

de quien va alegremente a joder en mi cama

en mi plato sin la alegría que merece

o que merecería si soy puro

viejo tony guiteras el curita los tantos

que atravesaron una vez la luz

no pensaron que yo sería ramón

sudaron porque sí porque la patria gritaba

porque todas las cosas estaban puestas al descuido

éste es mi tiempo lleno de alambres y beirut

de esa bomba callando

era verdad lo que juanito dijo

la felicidad es una pistola caliente

un esplendor impensado una rosa

todos tenemos alguna estrella en la puerta. $(S, 228)$

La insatisfacción, la amargura, el nihilismo, el individualismo, junto a motivos clásicos de la poesía como el tiempo, la muerte o el amor, serán los temas que la crítica ha insistido en clasificar como topos comunes de la nueva poesía. Antonio Merino, por ejemplo, señala que la nueva poética supone además un "mirarse hacia dentro para 'hurgar' los espacios interiores; la ternura, la inocencia, el juego, la fantasía, los sueños, el mun- 
do infantil, la memoria, la nostalgia, el cariño por las cosas y los objetos familiares»8. Habría que matizar sin embargo que ya «el mundo infantil» o «el cariño por las cosas y los objetos familiares» aparecen también en los versos de la poesía cubana a partir del 59, como señala Virgilio López Lemus en Palabras del trasfondo"; aún más: estos temas han estado presentes en la tradición poética de la isla, como puede comprobarse al revisar composiciones de Dulce María Loynaz, de Eliseo Diego o de Fina García Marruz, por citar algunos nombres. Pero creemos que hay una leve diferencia, y es que mientras esos poetas se sirven de los recuerdos para congraciarse con el presente, los de los 80 los rescatan para conformar una crítica directa al esquematismo ideológico y a lo demagógico.

Los jóvenes poetas ofrecerán un tipo de creación más oscura, críptica y compleja, con muchas referencias culturales; pero el coloquialismo -consciente o inconscientemente- también va a formar parte de su acervo emergiendo en algunos giros, expresiones o citas que no se habían incorporado al lenguaje poético antes del advenimiento del coloquialismo. Así podemos verlo en estos versos de Raúl Hernández Codina de «Quién seré sino el tonto...»:

Sobre la colina está solo and nobody seems to like him, pero él ve el mundo moverse a su alrededor, el sol rebotar como una pelota roja

en el horizonte. El sol tragado por el mar, frío entre los peces. (RM, 37)

Parece un lugar común de la crítica, algo que casi se ha convertido en una tendencia, achacar gran parte de los males de la poesía cubana al coloquialismo; pero no cabe duda de que contra los presupuestos teóricos unos movimientos se levantan otros, pero también lo es que unos asumen otros.

En cualquier caso, el agotamiento del anterior coloquialismo genera en esta década otro tipo de coloquialismo que se centra en un discurso que persigue un efecto narrativo. Lo que sí se ha agotado es la poesía de soflamas revolucionarias, pero no necesariamente esa forma poética que todavía puede dar muchos y valiosos frutos. De hecho, el agotamiento de las formas coloquiales más puramente revolucionarias y programáticas ha desembocado en la dispersión de formas y en la diversidad de voces.
Se podría decir de esta década pero también de la poesía de estos momentos que en ella, como en la de Pound, cabe todo, independientemente de la Revolución, y muy a pesar de ella. Esa libertad poética obtiene como resultado que no exista una escritura dominante sino que los poetas de esta década, y con más fruición los de la siguiente, mezclen el lenguaje sencillo con el altamente poético, y ello con la clara intención de activar contrastes. El resultado es la creación de un lenguaje que ayuda a reflejar la situación cubana actual en la que sin duda también son frecuentes esas diferencias. Pueden servirnos de ejemplo estos versos del poema de Luis Lorente, «Ella canta en La Habana»:

La Habana un paraíso extenso, casi blanco

donde abunda el coral.

Cuando tenga la noche y venga algún deseo,

tú, dios de los cronopios, aléjala de mí. (RM, 57)

Los poetas de los 80 manifiestan sin pudor su necesidad de alejarse del espacio real, de anhelar un nuevo lugar - el suyo-, de sentir que les corresponde elegir su camino; y lo harán, al igual que sus antecesores. En esta senda, el yo predominará sobre el nosotros, como ya apuntamos, $y$ el hecho de que el sujeto sea otro hace que, según León de la Hoz, se replantee «la relación entre obra-autor. Relación confidencial con el lector vs. oralidad en los $60 \gg^{10}$.

La mayor novedad, sin embargo, de la nueva poética está en el mensaje, que es buscadamente crítico, y los poemas se llenan de renuncia a las profecías y a las arengas como veíamos en el poema citado de Fernández Larrea; de ahí que la ironía y el sarcasmo - que habían casi desaparecido del discurso poético cubano desde el inicio de la Revolución-, tengan un lugar preeminente. Ahora el autor no tiene necesariamente que enfrentarse a su realidad, y puede optar por un discurso en el que primen las alegorías, las simbolizaciones, la fantasía, etc.

Quisiera llamar la atención en este punto y señalar la importancia de uno de los tópicos, el de los puentes, que más adeptos tendrá entre los poetas de la década de los 80 y la de los 90; tópico que les sirve de metáfora, de símbolo o de elemento alegórico. El término, que hace referencia a una situación provisoria y también al anhelo de llegar al otro extremo, es lo suficientemente ilustrativo de la situación de Cuba después de más de veinte años de Revolución. El
8

Antonio Merino, Nueva poesía cubana. (1966-1986), Madrid, Orígenes, 1987, p. XXVII.

9

El libro fue publicado en La Habana, Letras Cubanas, 1988. López Lemus hace una clasificación (pp. 96 a la 98) de los temas más frecuentes de la poesía cubana de los 60 .

10

La poesía de las dos orillas: Cuba (1959-1993), Madrid, Libertarias/ Prodhufi, 1994, p. 43.
Poesía cubana a finales del XX: 1980-2000

CARMEN ALEMANY BAY 


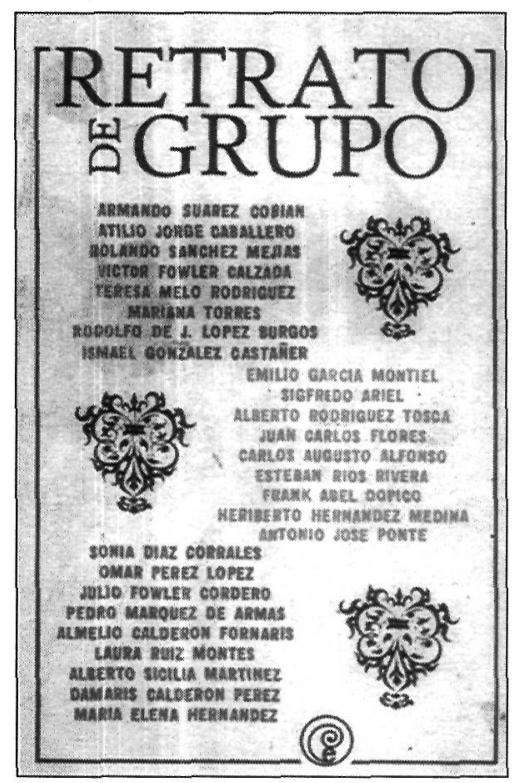

uso de este término refleja una situación real para muchos cubanos como es la situación de estar en medio y a la espera de la conclusión de un proyecto que no llega nunca; un período de transición que no parece tal por su estancamiento. Todo ello provoca en el poeta un sentimiento de decepción y desengaño que tiene su trasvase en la desconfianza del propio lenguaje, en las palabras que está utilizando.

El motivo de los puentes ya lo anticipó Fernández Larrea en su composición «Poema transitorio»:

Es difícil vivir sobre los puentes
Atrás quedó la negra boca el odio
y no aparece el esplendor
esto es también el esplendor
pero tampoco (Ud, 176)

11

Osmar Sánchez, «Poesía en claro. Cuba, años 80 (long play/ variaciones)», en Alicia Llarena, op. cit., p. 39.

12

Ésta es sólo una muestra de los muchos libros que los poetas de los sesenta publican en los ochenta. Un elenco más extenso lo da Antonio Merino en op. cit., p. XLIII.
Poesía cubana a finales del $\mathrm{XX}$ : 1980-2000

CARMEN ALEMANY BAY y aparecerá en algún poema de Reina María Rodríguez («Cuando se levantan los puentes» (RM, 79)). Le seguirán otras voces como la de Alberto Rodríguez Tosca en «Un puente es un puente en tanto sirve para cruzar al otro lado», pero además «Si estamos de éste, el otro lado es aquel/ si estamos de aquel, etc)»; también la de Heriberto Hernández en «La ciudad de los puentes se suicida, se adormecen el canto de sus muertos», donde reza lo siguiente:

En las escaleras han puesto montones de papeles para evitar que suba,

para evitar que salga a los balcones, el pecho abierto

y la ciudad como un testigo que exige un mínimo discurso,

un pedazo de corazón para lanzar del puente. (RM, 250)

En definitiva, como señala Osmar Sánchez, «En lo que respecta estrictamente al arte y a la vida cultural en general, no podía ser ésta sino una década de redefiniciones, de impugnación de ciertos cánones y modelos hegemónicos; de búsquedas, conquistas y experimentaciones inusuales o ya inusadas en la aún breve historia del arte de este período; de entronque con procesos detenidos en la articulación de los años 60 y 70 ... Como, en efecto, ha sido» ${ }^{11}$.

Sería aún más incompleto este apartado si no hiciéramos mención a la notable producción poética que desarrollan los poetas de los 60 en esta década. Del grupo de los 50, Fernández Retamar publica Juana y otros poemas personales (1980); Pablo Armando Fernández, Campo de amor y de batalla (1984); en el mismo año César López edita Quiebra de la perfección. De los poetas de «El Puente», Miguel Barnet da a conocer su Mapa del tiempo y Nancy Morejón, Piedra pulida (1986); algunos caimaneros como Raúl Rivero saca a la luz Poesía pública (1983) y Guillermo Rodríguez Rivera, En carne propia $(1984)^{12}$. Como era previsible sus poéticas respectivas no han cambiado pero sus versos, adaptándose a los nuevos vientos poéticos, denotan más intimismo y hay menor constancia de lo social: el nosotros de sus poemas ya se avecina más al yo.

Esta década de los 80 ha sido una de las más decisivas en la poesía cubana desde la segunda mitad del siglo XX, no sólo por el cambio de la temática poética sino por la incidencia en los poetas inmediatamente posteriores, porque la poesía sigue en los 90.

\section{LA POESÍA SIGUE EN LOS 90}

La década de los 90 se abre con una situación histórica y social bastante comprometida que se ve agravada con la caída de los países socialistas $y$, como consecuencia, los problemas económicos van haciendo mella en la sociedad cubana con la consiguiente depresión en la forma de vida, crisis de valores, etc. La poesía, al igual que en los comienzos de Revolución, no será ajena a los duros acontecimientos cotidianos; pero a diferencia de la década de los 60, los versos seguirán los temas y modos apuntados en los 80 en composiciones de corte reflexivo o antiutópico, sin descartar tonos existencialistas. La carencia de un destino claro en lo cotidiano tendrá su plasmación en lo poético.

Entre las múltiples carencias a las que se enfrentan los cubanos en la vida cotidiana está la falta de papel, lo que incide de manera directa en la publicación de libros. La cantidad de volúmenes que se publicaron en los primeros años de la Revolución contrasta con el número de ejemplares editados en esta década; de manera que una de las soluciones para que los poetas se den a conocer - aparte de los versos escritos en octavillas que pasan de mano en mano- es que sus poemas aparezcan en antologías. En esta línea, Osmar Sánchez señala la irregular situación editorial y apunta que la nueva literatura está emergiendo al 
margen de los libros ${ }^{13}$; y José Luis Arcos afirmará que «este último grupo de poetas ostenta ya el raro privilegio de haber sido el más antologado en toda la historia de la poesía cubana (...) Suelen repetirse los mismos poemas de una antología a otra»14. Quizá la más representativa, por su carácter de pionera, sea Retrato de grupo (1989) ${ }^{15}$, y también porque ahí se incluyen las principales voces poéticas de la Cuba de los 90: Armando Suarez Gobian, Atilio Jorge Caballero, Rolando Sánchez Mejías, Víctor Fowler Calzada, Teresa Melo Rodríguez, Mariana Torres, Rodolfo de Jesús López Burgo, Ismael González Castañer, Emilio García Montiel, Sigfredo Ariel, Alberto Rodríguez Tosca, Juan Carlos Flores, Carlos Augusto Alfonso Barroso, Esteban Ríos Rivera, Frank Abel Dopico, Heriberto Hernández Medina, Antonio José Ponte, Sonia Díaz Corrales, Omar Pérez López, Julio Fowler Cordero, Pedro Márquez de Armas, Almelio Calderón Fornaris, Laura Ruiz Montes, Alberto Sicilia Martínez, Damaris Calderón Pérez y María Elena Hernández Caballero ${ }^{16}$. A estos nombres habría que añadir otros, algunos más recientes, como Nelson Simón González, Ronel González Sánchez, Odette Alonso Yodú, José Féliz León, Norge Espinosa Mendoza, Liudmila Quincoses Clavero, León Estrada, Wendy Guerra Torres, Ernesto Ortiz Hernández, Arístides Vega Chapú, Alcides Herrera Duarte, Juan Carlos Valls Hernández, Bárbara Yera León.

Retrato de grupo, como su propio nombre indica, es una muestra de autores - todos ellos bastante jóvenes y, consecuentemente, con poca obra publicada- que, como subrayará Jorge Cabezas Miranda, «se han formado íntegramente dentro del proceso revolucionario. Estos autores comienzan a escribir a partir de los años ochenta, momento en el que se dan una serie de circunstancias convulsas de orden social y político que remueven los cimientos insulares y que van a modificar la realidad de los cubanos ${ }^{17}$.

La antología citada y las que le seguirán nos dan una idea vaga del camino por el que en un futuro próximo seguirán estos autores; pero sí encontramos «el deseo expreso o tácito en la mayoría de estos poetas - como explicita José Luis Arcos- de no escribir poesía conversacional. Esto no implica en ningún modo que en la práctica no utilicen recursos retóricos propios de aquella moda-

lidad poética, ni que renuncien a las ganancias de la oralidad, del habla, de la conversación: conquistas, por lo demás, de la poesía contemporánea y, en el contexto iberoamericano, una calidad y una cualidad poéticas adquiridas ya por nuestro modernismo» ${ }^{18}$. En cualquier caso, los jóvenes buscan desesperadamente una formación individual; y la experiencia personal, el individualismo, y lo cotidiano, también serán perfectamente compatibles con la inclusión de la coloquialidad en el discurso.

A este respecto, es bastante elocuente y descriptiva la opinión de Nidia Fajardo sobre las características formales y temáticas de los autores que componen Retrato de grupo:

\section{Aprovechan todas las posibilidades del} juego polisémico para proponer más de una lectura y estimular las capacidades de recepción de cada lector. Esto hace que desechen el sentido directo, inmediato u obvio de los términos, con lo que logran desautomatizar el discurso y, precisamente, la recepción (...) Hay, además, una marcada tendencia a la fabulación, la alegorización y el uso de las parábolas. Lo cotidiano puede estar en estas obras, pero casi siempre asaltado por la magia (...) Desde el punto de vista estilístico, se puede observar una tendencia hacia la densidad metafórica. En muchos casos hay rupturas sintácticas, inconsecuencias predicativas y coordinativas, rupturas de sistema, recursos que aparentemente hacen que se toque el absurdo (...) Trabajan cualquier textura verbal, desde las referencias cultas hasta las «malas palabras», desde los textos en otras lenguas hasta el juego intertextual, los préstamos, las citas (...) La «alta cultura» $\mathrm{y}$ el kitsch; la poesía de Lezama, Vitier o Diego y el último texto de un rock (...) dicen de la riqueza y la fuerza de la poesía cubana de hoy ${ }^{19}$.

13

«Poesía en claro. Cuba, años 80 (long play/ variaciones)», en Alicia Llarena, op. cit., pp. 33-79.

14

En «¿Otro mapa del país? Reflexión sobre la nueva poesía cubana», Temas, 3, julio-septiembre, 1995, p. 121.
15

Jorge Luis Arcos, en el artículo citado en la nota anterior, da cuenta de las numerosísimas antologías publicadas a finales de los $80 \mathrm{y}$ comienzos de los 90 , tanto en Cuba como en otros países latinoamericanos o en España. Lo destacable es que en todas ellas se suelen repetir los nombres incluidos en Retrato de grupo.

16

Algunos miembros de este grupo, Carlos Augusto Alfonso Barroso y Omar Pérez, con anterioridad, ya habían dado a conocer lo renovador de su poética. En 1983, Casa de las Américas organizó un recital en el que participaron estos autores $y$ su lectura provocó un gran revuelo por lo novedoso de su mensaje, basado en la denuncia a los aspectos negativos que la Revolución había generado.

17

Novisima poesía cubana. Antología (1980-1998), Salamanca, Ediciones Colegio de España, 1999 , p. 22.

\section{8}

Op. cit., p. 123.

19

De transparencia en trasparencia. Antología poética (selección y prólogo de Nidia Fajardo Ledea), pp. 14-15. Por su parte, León de la Hoz (en op. cit., p. 14) divide el periodo poético de la Revolución en tres etapas: «En la primera (1959-1968) tiene lugar el movimiento de los 60 que devela 'lo conversacional', en la segunda (1969-1980) otro movimiento, el de los 70, que agota lo conversacional; $y$ la tercera etapa (1981- hasta la fecha) con un movimiento de los 80 caracterizado por la síntesis, que aún no parece haber llegado a su coda definitiva». Sobre la poesía de los 90, el citado crítico apunta: «Hoy, en los 90 , en la antesala del próximo siglo, los poetas de todas las generaciones no sólo han encontrado un estado de cosas parecido en cuanto a esa supervivencia, en una sociedad urgida de pensarse a sí misma y acudir a la espiritualidad viva en el reservorio cultural de la nación, sino que también hallaron una profunda depresión en la calidad de vida unida al trauma de una de las más promisorias utopías y a la crisis de valores que afecta al mundo, calificada eufimísticamente postmodernista por los teóricos» (p. 43).

Poesía cubana a finales del XX: 1980-2000

CARMEN ALEMANY BAY 

que pasó llorando", El País, Madrid, 2 de agosto de 1998, p. 9.
Poesia cubana a finales del XX: 1980-2000

CARMEN ALEMANY BAY
Por tanto, una poesía que cuestiona las grandes disertaciones y que pone en entredicho la función social de la poesía, aunque ello no implique el olvido de la historia de su país, sino evidenciar los errores derivados de la Revolución: el tabú de la homosexualidad, la doble moral, la hipocresía, etc. Esta variedad de temas llevará consigo la heterogeneidad de los discursos, que es sin duda la principal característica de la poesía última. Una forma de aproximación a esta variedad de lenguajes y de temas es la de examinar algunas de las voces que por su originalidad o por su notoriedad creativa están en la primera línea de la poesía cubana actual.

No es gratuito que empecemos con la poesía de Heriberto Hernández Medina, por ser una de los más significados dentro del hermetismo reinante en la poesía de los 90. La complejidad en sus poemas es en ocasiones algo forzado, pero, cuando no lo es y sabe combinar esas características con lo cotidiano, no podemos sino reconocer su profundo talento:

- Yo amaba la lejanía, su horizonte tan turbio y era dulce la ausencia;

yo, eterna interrogada, fui condenada a amar esta tristeza,

esa muchacha que buscáis

es una música negada al hombre, un arpa que en el sueño

traza arabescos en vuestros pechos de animales felices,

ella es la verdad, vuestra verdad en el espejo «La patria del espejo» $(\mathrm{Tr}, 93)$

La profusión de adjetivos o el uso insistente de la primera persona son dos pilares fundamentales de su creación; como también lo son para Rolando Sánchez Mejías quien, según Arcos, «asume conscientemente, como una voluntad creadora, la diversidad de estilos dentro de su praxis escritural $\rtimes^{20}$. Y añadirá que tanto Rolando Sánchez Mejías como Omar Pérez López son «los que de una manera más profunda y radical ejemplifiquen la ruptura y la edificación de una nueva norma; ningún poeta de la hornada anterior ha llegado más lejos que ellos»²1.

A modo de ejemplo puede servirnos el poema "Discursos de los párpados de arena» (R, 18), de Rolando Sánchez, donde el autor presenta una poética oculta tras una tópica serie de imágenes que se nos presentan en la úl- tima parte del poema («Hoy se nos destinó a decir adiós en andenes/vacíos...»); sin embargo, no se nos escapa la propia reflexión sobre la escritura poética cuando el poeta nos dice: «Claro que esperábamos otra cosa/ a la vuelta de los grandes asuntos» o "No sé de qué más podemos hablar».

Como se apuntaba más arriba, Omar Pérez López comparte con Sánchez Mejías «la ruptura y la edificación de una nueva norma», no en vano éste último es considerado, por estos motivos entre otros, como uno de los autores fundacionales de esta última poética cubana. Su poesía, junto con la de Carlos Augusto Alfonso, introduce «un sello revisionista, de denuncia, pero con aspecto altamente civilizador, sin traumas o violencias» ${ }^{22}$; y así podemos comprobarlo en su composición «Yo ataqué Moncada». Aquí el autor ironiza sobre el tema de la lucha utilizando un recurso muy habitual en la poesía de lucha nacionalista. Carlos Augusto Alfonso dirá: «viejecita llorosa que me ves pasar desde el balcón/ yo sobreviviré a esos fuegos artificiales pues no son/ para mis ojos». Según Mario Vargas Llosa, fue el gran poeta William Batler Yeats quien en su drama patriótico irlandés Catheleen ni Houliban (1902) «inventó aquella imagen de larga reverberación en las mitologías nacionalistas de la vieja que pasó llorando, personificación de la Patria, claro está, humillada y olvidada, esperando a que sus hijos la rediman» ${ }^{23}$.

También el aspecto desmitificador se verá en la poesía de Antonio José Ponte y, específicamente, en el poema «En diciembre viendo volar los fuegos de artificio" ( $\mathrm{R}, 115)$ que hace referencia a la fiesta de la Nochevieja. Para el poeta el año no empieza el uno de enero, sino el día de su cumpleaños, y lo demás, no es sino una convención para poner a todos de acuerdo. De este modo, el poeta no cuenta los años, sino sus años: «Un año no comienza en esta noche/ hecha para que algunos abracen y rían, / sino en la calma mañana de mi cumpleaños».

Pero más interesante será la composición «Discurso del día del juicio» ( $R, 116-118)$ donde aparecen las palabras «Pisando la dudosa luz del día» (último verso de la estrofa 9 de la Fábula de Polifemo y Galatea de Luis Góngora); éste le servirá para encabezar la composición «Glosa a Luis de Góngora» (PC, 156). Llamamos la atención sobre estos 
poemas porque si bien es frecuente encontrar la cita culta entre los versos de la poesía última cubana (el mismo autor nos la da en otros poemas como «A la manera de Brecht» (PC, 157) o "Confesiones de San Agustín, Libro IX, Capítulo $\mathrm{X}$ » $(\mathrm{PC}, 158)$ donde encontramos a San Agustín y a Santa Mónica como protagonistas del poema), las citas pocas veces hacen referencia a poetas españoles. En cualquier caso, la poesía de este autor «o la de Emilio García Montiel, dables de identificar dentro de un conversacionalismo lírico, resultan dos de las poéticas más características de la nueva norma; o que una poesía como la de Rodríguez Tosca, Alfonso o Frank Abel Dopico - acaso del linaje de la de Fernández Larrea- porten tantos elementos de ruptura» ${ }^{24}$.

Desde el «conversacionalismo lírico», García Montiel hará una crítica, en actitud de desafío, a la realidad impuesta por la sociedad revolucionaria, y en esa misma actitud estará Damaris Calderón en poemas como «Ésta será la única mentira en la que siempre creeremos» ( $R, 165)$, en donde se refleja la conciencia de lo inseguro de la comunicación, vinculada al desengaño de los ideales revolucionarios («jugar a ser perfectos» $)^{25}$. La autora, al igual que García Montiel, se atreve a mirar las circunstancias reales que la envuelven, aunque ello no vaya a acarrearle más que desilusión, de modo que pueda llegar a compararse —a diferencia de García Montiel- con un suicida. Esta comparación también la hallamos en el «Autorretrato» de Helena Hernández.

La insistencia del poeta como loco, o incluso como suicida, es bastante frecuente en la poética cubana de las últimas décadas. A los ejemplos expuestos habría que añadir otros como la composición «Submundo» $(\mathrm{R}, 169)$, de la ya citada Helena Hernández ( aguarda bajo el brazo/ su poco de nada»); el verso de Almelio Calderón: «soy un pequeño loco de estación gris», en «Fugacidad» $(R$, 149); o el de Alberto Sicilia Martínez, «loco cerrando los ojos», en «Huesped» $(\mathrm{R}, 160)$. Pero ya a comienzos de los 80 algunos poetas incidieron en esta misma idea. Raúl Hernández Novás (1948), por ejemplo, habla de «el loco, el tonto que siempre he sido».

En cualquier caso, la soledad y el desengaño de la realidad serán uno de los temas más recurrentes en las voces ya citadas, y en otras como la de Atilio Jorge Caballero y Almelio Calderón Fornaris. Éste último nos describe

espacios de soledad desesperada que contrastan con su preocupación por el mundo; de ahí su voluntad de sumarse a «las nuevas gargantas de los hombres», verso que podría interpretarse también como la voluntad de adherirse a la nueva poesía y liberarse de los moldes anteriores. No en vano, en «Tendré que morder una estrella» manifiesta ese deseo de romper con las ilusiones utópicas y buscar nuevos caminos: se siente defraudado por las esperanzas que le fueron inculcadas en su infancia y recurre a la poesía como canal de expresión para esos sentimientos. Pero la poesía con la que se encuentra no puede satisfacer tampoco su voluntad de comunicación.

En este punto queremos retomar parte de una cita anterior, que «una poesía como la de Rodríguez Tosca, Alfonso o Frank Abel Dopico - acaso del linaje de la de Fernández Larrea- porten tantos elementos de ruptura». Precisamente, Frank Abel Dopico representará otra de las múltiples vías temáticas que aparecen en la actual poesía cubana; él será el poeta del surrealismo, del sueño y de la fantasía, de ahí que sus composiciones nos remitan a estados o situaciones imaginarias, como se ve en «La próxima ciudad», donde el autor pide a gritos construir una ciudad, hacerla mejor o peor pero hacerla él; en el fondo, subyace el deseo de crear su espacio en esa ciudad:

como si estuviéramos locos y contáramos el
aire por parejas
hagamos bien o mal otra ciudad, minúscula.

Sí.

Gato a gato vamos a hacer otra ciudad (PC, 186).

Algunos poetas centrarán su discurso lírico en la utilización de elementos simbólicos como Jorge Yglesias, mientras otros se inclinarán por «discursos de vocación filosófica como el de Lourdes Rensoli; o hasta en esa poética histórica, sustentada en la imagen, de Efraín Rodríguez» ${ }^{26}$.

En definitiva, la última poesía cubana ha dejado paso franco a absolutamente todas las tendencias, incluso a las marginadas y marginales. Así, como marginal, se podría considerar hace unos años la poesía de Norge Espinosa $y$, específicamente, su composición «Vestido de novia» (perteneciente a Breves tribulaciones (1992)), encabezada por unos versos de García Lorca, «Oda a Walt Whitman»,

\section{4}

Jorge Luis Arcos, op. cit., p. 124.

25

Un caso paradigmático de crítica a lo impuesto será el de M. Elena Cruz Valera, autora que por edad pertenecería al grupo de los 80 , pero su discurso tiene plena vigencia en los 90. De manera personal y poética, Cruz Valera, desde una actitud contrarrevolucionaria, propugnará un cambio social. Encarcelada dos años por difamaciones, $y$ en sucesivas ocasiones en un psiquiátrico por «neurosis nerviosa", promovió la "Caria de los diez», en la que intelectuales cubanos pedian a Fidel Castro cambios inmediatos; también fue la fundadora del grupo «Criterio Alternativo" y fueron numerosas las cartas que envió al mandatario cubano dando su opinión sobre la situación del país, lo que provocó su expulsión de la UNEAC y el repudio público. Su poesía, lógicamente, denunciará el confinamiento, la prohibición y el suyo será un discurso de resistencia frente al poder.

26

Jorge Luis Arcos, op. cit., p. 124.
Poesía cubana a finales del XX: 1980-2000

CARMEN ALEMANY BAY 
Este texto fue incluido en Roberto Fernández Retamar, Ensayo de otro mundo, La Habana, Instituto del Libro, 1967, p. 83.

30

Publicado en Al borde de mi fuego. Poética y poesía hispanoamericana de los sesenta, Alicante, Casa de las Américas/ Universidad de Alicante, 1998, p. 34 . y cuyo contenido - que tuvo gran repercusión en la isla por las atrevidas imágenes homosexuales allí reflejadas- recuerda a los poemas más sensuales del poeta granadino. Lo que fue considerado como antipatriótico, la condición de homosexual, en los primeros años del proceso revolucionario, es ahora un tema descrito sin rubor.

Además de la amalgama de tendencias, la falta de perspectiva temporal complica terriblemente el estudio de esta última década pero, lo que es más importante, enriquece extraordinariamente el tipo de poesía que se hace. Como ha apuntado Arcos: «No es el vacío, la intemperie de valores, su punto de partida, en todo caso son las ruinas, son los ecos, por un lado, de un sistema anterior, y, por otro, sus nuevas preguntas y respuestas ${ }^{27}$. Más explícito será Jorge Cabezas Miranda cuando señala que «la poesía cubana se encuentra en un proceso de búsqueda, tal vez se encuentren los poetas, fieles representantes del sentir cubano actual ${ }^{28}$. Lo cierto es que la poesía cubana en estos momentos se encuentra en un círculo que da vueltas sobre sí mismo sin lograr desligarse de los duros momentos que se viven en la isla. Sírvanos para lo que acabamos de afirmar una cita de Víctor Fowler, quien, en un artículo de título bastante significativo, "Comunicación-comprensión: claridad. Olvidar los sesenta», saca a colación un párrafo que Roberto Fernández Retamar escribió para una antología que nunca llegó a publicarse. Retamar compara los títulos de obras publicadas antes de la Revolución con otras publicadas después del 59. El párrafo decía así:

Bastaría comparar los títulos de aquella generación con los de ésta para verificar ese cambio. De Enemigo rumor (1945), Extrañeza de estar (1946), Las miradas perdidas (1951), Por los extraños pueblos (1958) hemos pasado a Vuelta de la antigua esperanza (1959), Himno a las milicias (1961), Por esta libertad (1962), El justo tiempo bumano (1962), Libro de los béroes (1964). Pero es, desde luego, más que cuestión de títulos. De la oscuridad hemos pasado a la abertura; de la nostalgia a la esperanza; de la extrañeza, a la certidumbre ${ }^{29}$.

Hábilmente, Fowler apostillará:

Podemos hacer ahora lo mismo que entonces y seguir hasta El arte de la fuga (1992), Con el terror del equilibrista (1992), Los altos manicomios (1993), El arte perdido de la conversación (1993), El encanto perdido de la fidelidad (1993), Derivas (1993), Diario del ángel (1994), Páramos (1994), Descencional (1994). Si nos fijamos en los títulos parece el tiempo de olvidar los sesenta ${ }^{30}$.

La poesía sigue. 